\title{
Decision support for water quality management of contaminants of emerging concern
}

Astrid Fischer ${ }^{1}$, Thomas ter Laak ${ }^{2}$, Jan Bronders ${ }^{3}$, Nele Desmet ${ }^{3}$, Ekkehard Christoffels ${ }^{4}$, Annemarie van Wezel ${ }^{2,5}$, Jan Peter van der Hoek ${ }^{1,6}$

${ }^{1}$ TU Delft, Faculty of Civil Engineering and Geosciences, PO Box 5048, 2600 GA Delft, The Netherlands ${ }^{2} \mathrm{KWR}$ Watercycle Research Institute, Nieuwegein

${ }^{3}$ Flemish institute for technological research (VITO), Antwerpen

${ }^{4}$ Erftverband, Bergheim

${ }^{5}$ Copernicus Institute, Utrecht University

${ }^{6}$ Waternet, Strategic Centre, Amsterdam

\section{Contents}

\section{E-mail contact: a.fischer@tudelft.nl}

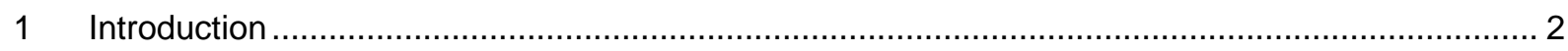

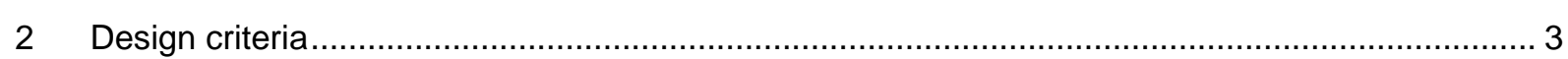

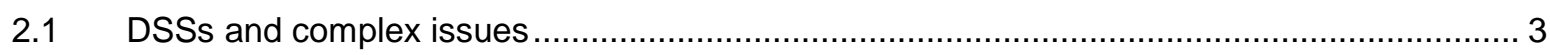

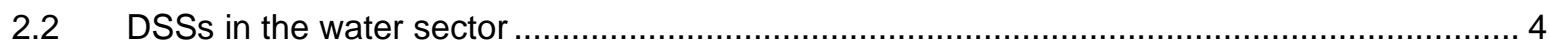

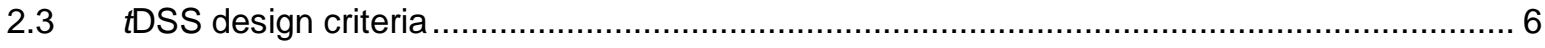

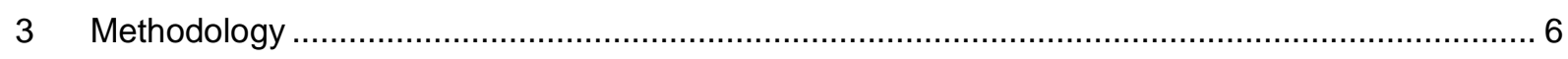

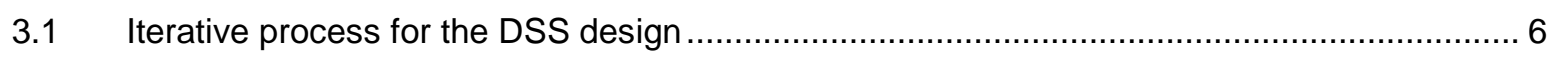

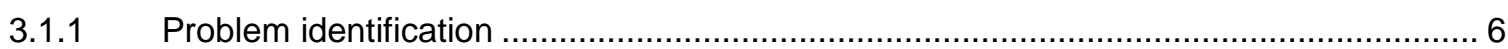

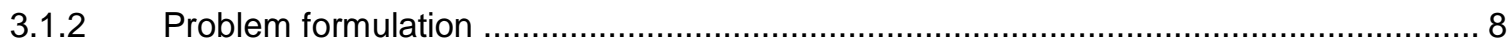

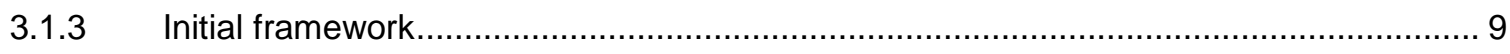

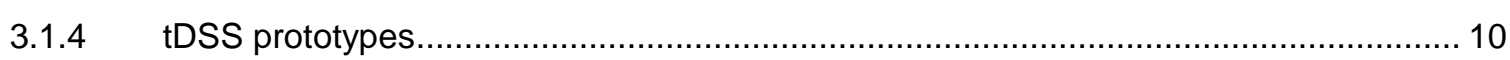

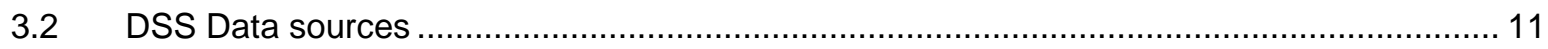

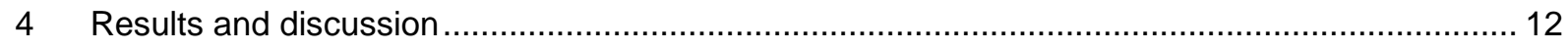

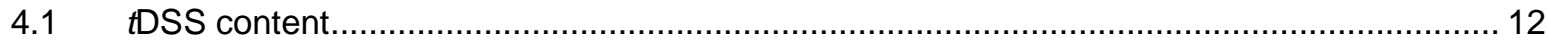

4.1.1 Substance characteristics and physical/chemical properties ................................ 12

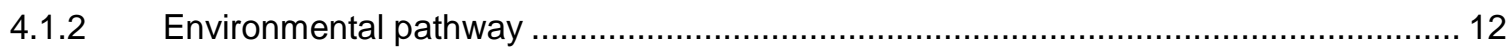

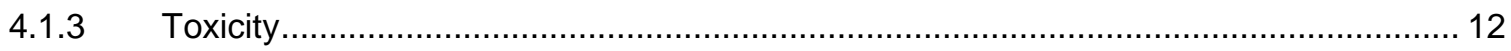

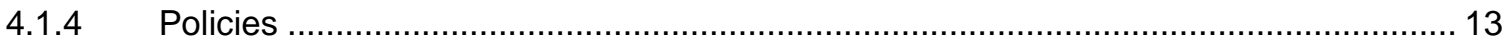

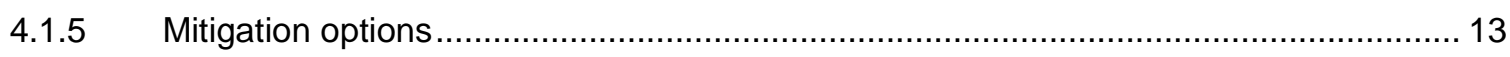

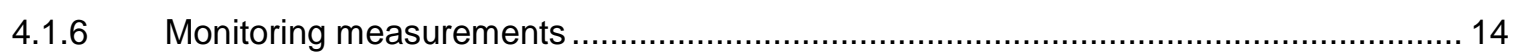

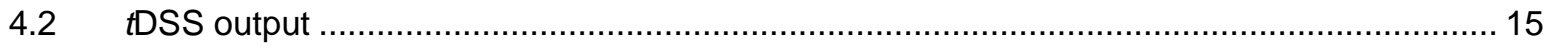

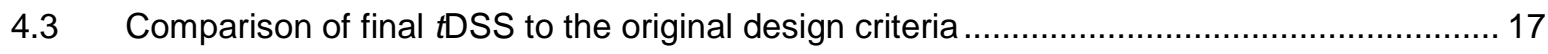

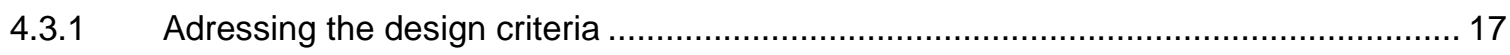

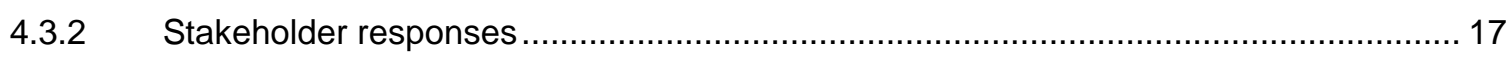

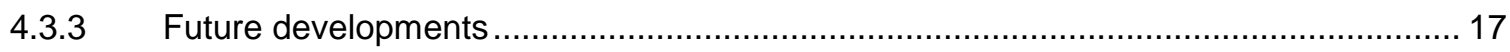

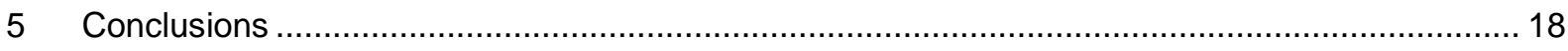

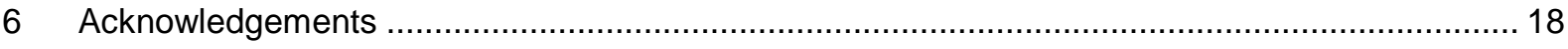




\section{Abstract}

Water authorities and drinking water companies are challenged with the question if, where and how to abate contaminants of emerging concern in the urban water cycle. The most effective strategy under given conditions is often unclear to these stakeholders as it requires insight into several aspects of the contaminants such as sources, properties, and mitigation options. Furthermore the various parties in the urban water cycle are not always aware of each other's requirements and priorities. Processes to set priorities and come to agreements are lacking hampering the articulation and implementation of possible solutions.

To support decision makers with this task, a decision support system was developed to serve as a point of departure for getting the relevant stakeholders together and finding common ground. The decision support system was iteratively developed in stages. Stakeholders were interviewed and a decision support system prototype developed. Subsequently, this prototype was evaluated by the stakeholders and adjusted accordingly. The iterative process lead to a final system focused on the management of contaminants of emerging concern within the urban water cycle, from wastewater, surface water and groundwater to drinking water, that suggests mitigation methods beyond technical solutions. Possible wastewater and drinking water treatment techniques in combination with decentralised and non-technical methods were taken into account in an integrated way. The system contains background information on contaminants of emerging concern such as physical/chemical characteristics, toxicity and legislative frameworks, water cycle entrance pathways and a database with associated possible mitigation methods. Monitoring data can be uploaded to assess environmental and human health risks in a specific water system. The developed system was received with great interest by potential users, and implemented in an international water cycle network.

Keywords: contaminants of emerging concern, water quality management, urban water cycle, drinking water treatment, wastewater treatment, abatement methods.

\section{Introduction}

Chemicals are continuously produced for various beneficial purposes, such as protecting crops, conserving food or treatment of diseases. Over 3470.000 chemicals are registered and regulated via national and international authorities (CHEMLIST), new chemicals enter the market continuously and the global volume of production of chemicals is growing (CEFIC, 2013). Many of these chemicals and their transformation products enter the aqueous environment during their life cycle (Schwarzenbach et al., 2006).

Preliminary risk assessments consistently show that these environmental concentrations are lower than required for adverse human health effects, hence for individual compounds risks are not expected (Bruce et al., 2010; de Jongh et al., 2012; Debroux et al., 2012; Houtman et al., 2014; Schriks et al., 2010). However the toxicological risk of summed concentrations in complex environmental mixtures is heavily debated, especially related to potential endocrine disruption (Bergman et al., 2013; Dietrich et al., 2013; Nohynek et al., 2013; Vandenberg et al., 2012). This causes increasing concern for the public, regulators and users of surface water (Diamond et al., 2015; Schwarzenbach et al., 2006).

There are many definitions of these contaminants of emerging concern (CECs), but in this article the following definition is used: "manufactured or manmade chemicals or materials which have now been discovered or are suspected to be present in various environmental compartments and whose toxicity or persistence are likely to significantly alter the metabolism of a living being" (Sauvé and Desrosiers, 2014). CECs include, but are not limited to, drugs of abuse, artificial sweeteners, pesticides and biocides, musks and fragrances, perfluorinated compounds, industrial substances, nanoparticles, 
plasticisers, pharmaceuticals and transformation products of these chemicals (Richardson, 2012; Richardson and Ternes, 2011).

Information on CECs multiplies with rapid speed. Several legal frameworks, e.g. the Water Framework Directive (WFD) and the EU chemicals regulation (REACH), are dealing with the issue both from a water quality and authorisation perspective (EU, 2000, 2006). However water quality legislation, both on a national and international level, are not meant to cover all individual substances authorised on the market (Houtman, 2010). Furthermore there is often a time lag from the time a compound with adverse effect is observed in the environment, to the time that the necessary legislation or policy is implemented (Christensen et al., 2011; Halden, 2015). The time lag is due to complex decision structures and the need for compromises (Halden, 2015; Houtman, 2010). This leaves water authorities and drinking water companies with the question if, where and how to abate these substances in the urban water cycle.

Many strategies are available to mitigate emissions. During the design and production stage of the chemicals, legal regulations are in force. During the use stage, strategies such as drift reduction can be used, especially for professional uses such as pesticides. Finally in the waste and removal stage, strategies such as take-back schemes for pharmaceuticals or treatment of wastewater and drinking water can be implemented (Schirmer and Schirmer, 2008). The most effective strategy under given conditions are often not clear to stakeholders. It requires insight into several aspects of the contaminants such as sources, properties, mitigation options, and their costs and benefits. Furthermore, multiple stakeholders (such as water boards, drinking water companies and municipalities) are often not aware of each other's requirements and priorities. Finally, processes to set priorities and come to agreements are lacking and this hampers the finding and implementation of possible solutions. The setup of river basin management plans required by the WFD address this issue (EU, 2000).

In 2013 the European Interreg programme funded the TAPES programme (Transnational Action Programme on Emerging Substances), with the aim to create a joint knowledge platform on CECs in the urban water cycle. As part of this knowledge platform a Decision Support System (DSS) was developed in strong cooperation with stakeholders within the whole water cycle. The objective of the DSS was to facilitate decision makers with the complex task of deciding on effective and efficient strategies to control CECs within their segment of the water cycle. To our best knowledge, no such DSS exists at this moment. In this paper the development process of this DSS is described, starting with the design criteria and finishing with the final DSS.

\section{Design criteria}

\subsection{DSSs and complex issues}

The definition of DSSs (Power and Sharda, 2009) is "an interactive computer-based system that helps people use data, documents, knowledge, and models to solve problems and make decisions". DSSs are built to support people in making decisions, not to make the decision itself (Angehrn and Jelassi, 1994; Power and Sharda, 2009). DSSs are regularly used by decision makers all over the world (Delpla et al., 2014; Mysiak et al., 2005; Power and Sharda, 2009). There is no consensus on the classification of various types of DSSs (Holsapple, 2003; Power and Sharda, 2009). The categorisation by Power (2002) is the one that will be used here:

1. Communication-driven; DSS includes communication and collaboration supported by technologies such as e-mails, bulletin boards, chat systems and interactive videos.

2. Data-driven; DSS gives access to tools to manipulate large sets of data.

3. Document-driven; DSS can be used to retrieve and analyse documents, such as product specifications, minutes of meetings, policies and procedures.

4. Knowledge-driven; DSS suggests actions within a specific domain. 
5. Model-driven; DSS gives access to a quantitative model.

Most DSSs are hybrids and consist of two or more of the above mentioned drivers (Power and Sharda, 2009).

DSSs shifted with time from solving semi-structured problems, to solving complex issues such as 'wicked' problems (Beynon et al., 2002; Courtney, 2001; McCown, 2002; Mysiak et al., 2005;

Rauscher, 1999). The characteristics of a 'wicked' problem is that stakeholders cannot easily agree on the problem definition, and options for solutions are not clear beforehand (Rittel and Webber, 1973). To solve 'wicked' problems, a collectively accepted solution is required (Hocking et al., 2015). Therefore the main focus should be on the problem formulation, based on discussions with stakeholders, to incorporate their perspectives (Mitroff and Linstone, 1993; Shim et al., 2002) and to ensure that all relevant variables are included in the analysis (Shim et al., 2002; Wassen et al., 2011).

DSSs have several pitfalls that need to be accounted for in the design phase (McBride, 1997; Mysiak et al., 2005; Newman et al., 1999; Wassen et al., 2011). Common pitfalls are:

1. The process of decision making goes together with a learning process (Salewicz and Nakayama, 2004). It is difficult to know beforehand what information is needed to make decisions.

2. The acceptability of a DSS links to the stakeholders' possibilities to contribute and their abilities to communicate results, rather than the credibility of the underlying model (scientific soundness, high quality data etc.) (Wassen et al. 2011). Acceptability by the stakeholders is often known only at the last phase of the DSS development.

3. In order to meet new or more complex requirements of the decision makers, a DSS constantly needs to be kept up-to-date and further developed, otherwise it quickly becomes obsolete (Newman et al., 1999).

\subsection{DSSs in the water sector}

DSSs are widely used in the water sector, mostly related to river management (Salewicz and Nakayama, 2004; Xu et al., 2007). DSSs are developed to help implementing aspects of the EU Water Framework Directive (WFD), such as MULti-sectoral INtegrated and Operational decision support system (MULINO), SOurce COntrol of Priority Substances in Europe (SOCOPSE), and the WFD Explorer (Baartmans et al., 2009; Giupponi, 2007; Junier and Mostert, 2014).

Many of the river management DSSs implicitly take CECs into consideration, for instance in combination with nutrients, but without attention for their specific behaviour, toxicity or mitigation options (Delpla et al., 2014). In most fresh water-related DSSs the whole urban water cycle from wastewater, surface water and groundwater to drinking water, is not taken into account. The systems usually focus on only one part, either drinking water, wastewater and/or surface water (Delpla et al., 2014; EPA, 2007; Junier and Mostert, 2014; WHO/IWA, 2009).

Table 1 gives an overview of the existing fresh water-related decision support systems that includes CECs. SOCOPSE and WFD-Explorer are the only two DSSs (not under development), which specifically can address CECs and possible mitigation strategies, and will therefore be discussed further. In general, the usefulness and success of a DSS can be difficult to assess. For the WFDExplorer, a paper on the development and use of the system, concluded that the tool was generally not used as hoped for. This was due to issues concerning the definition of the user group, the appropriate level of analysis and the expertise to be included (Junier and Mostert, 2014). A new and improved version was released in 2013 , which has not been evaluated yet, but was used to study mitigation measures for pharmaceuticals (Coppens et al., 2015). With regards to the SOCOPSE DSS, no evaluation of the success was found, however it has been used within the project for five case studies (www.socopse.se ). One of the learning points was that not all stakeholders necessarily had 
the same level of knowledge. This is when a DSS can help to level out this difference, and serve the relevant stakeholders to find common ground (personal communication R. Baartmans). The usefulness of SOCOPSE was reviewed in a master thesis from Uppsala University, and was found valuable, but points of improvements were also given (Andersson, 2009). None of both DSSs provides an information basis directed towards management of CECs in general, within the whole urban water cycle. Also none of the two DSSs address mitigation methods in an integrated way, such as wastewater and drinking water treatment techniques, in combination with decentralised and nontechnical methods. With non-technical methods we think of mitigation methods that fall within managerial, legal or societal actions such as temporarily stop the intake of drinking water, lobby for restrictions/bans of certain compounds, or increase awareness of the consequences of using certain compounds/products.

The objective of the DSS developed within the TAPES project framework, is to fill these gaps, as this is seen as a valuable addition to the existing fresh water-related CEC DSSs. Such a DSS will facilitate decision makers with the complex task of deciding on effective and efficient strategies to control CECs within their segment of the water cycle. The aim is to do this by providing CEC specific information on mitigation options relevant to the whole urban water cycle, including both centralised (wastewater and drinking water treatment techniques) and decentralised (such as direct water treatment at hospitals for example) technical mitigation options, as well as non-technical options. The developed DSS will be referred to as the TAPES DSS ( $t D S S$ ) in the remainder of this paper.

Table 1. Table of existing fresh water-related decision support systems that include CECS

\begin{tabular}{|c|c|c|c|c|c|c|}
\hline Name & $\begin{array}{l}\text { Organisation/ } \\
\text { Project }\end{array}$ & Type & Applicable for & Description & Year & References \\
\hline MULINO & $\begin{array}{l}\text { The MULINO } \\
\text { consortium/ } \\
\text { EU FP5 }\end{array}$ & $\begin{array}{l}\text { Computer } \\
\text { system CD- } \\
\text { ROM }\end{array}$ & $\begin{array}{l}\text { Competent } \\
\text { water authorities }\end{array}$ & $\begin{array}{l}\text { Enables sustainable use of } \\
\text { water resources at a catchment } \\
\text { scale. }\end{array}$ & 2004 & $\begin{array}{l}\text { (Giupponi, } \\
2007 \text { ) }\end{array}$ \\
\hline HACCP & EPA (USA) & $\begin{array}{l}\text { Guidance } \\
\text { document }\end{array}$ & $\begin{array}{l}\text { Drinking water } \\
\text { suppliers }\end{array}$ & $\begin{array}{l}\text { Enables identification and } \\
\text { control of microbiological } \\
\text { contamination in the distribution } \\
\text { system. }\end{array}$ & 2007 & (EPA, 2007) \\
\hline SOCOPSE & $\begin{array}{l}\text { The } \\
\text { SOCOPSE } \\
\text { consortium/ } \\
\text { EU FP6 }\end{array}$ & $\begin{array}{l}\text { Guidance } \\
\text { document }\end{array}$ & $\begin{array}{l}\text { Water } \\
\text { authorities }\end{array}$ & $\begin{array}{l}\text { Enables management of EU } \\
\text { priority substances at European, } \\
\text { national or river basin level. }\end{array}$ & 2009 & $\begin{array}{l}\text { (Baartmans et } \\
\text { al., 2009) }\end{array}$ \\
\hline $\begin{array}{l}\text { Water Safety } \\
\text { Plan Manual }\end{array}$ & WHO/IWA & $\begin{array}{l}\text { Guidance } \\
\text { document }\end{array}$ & $\begin{array}{l}\text { Drinking water } \\
\text { suppliers }\end{array}$ & $\begin{array}{l}\text { Enables development and } \\
\text { implementation of Water Safety } \\
\text { Plans to systematically assess } \\
\text { and manage risks. }\end{array}$ & 2009 & $\begin{array}{l}\text { (WHO/IWA, } \\
\text { 2009) }\end{array}$ \\
\hline ARTEM-WQ & $\begin{array}{l}\text { LERES } \\
\text { (France) }\end{array}$ & $\begin{array}{l}\text { Computer } \\
\text { system }\end{array}$ & $\begin{array}{l}\text { Small water } \\
\text { supply systems }\end{array}$ & $\begin{array}{l}\text { Calculates a health assessment } \\
\text { based on water quality (with } \\
\text { regards to micro pollutants), } \\
\text { catchment type, treatment in } \\
\text { place and DOC removal. }\end{array}$ & 2013 & $\begin{array}{l}\text { (Delpla et al., } \\
\text { 2014) }\end{array}$ \\
\hline WFDE & Deltares & $\begin{array}{l}\text { Computer } \\
\text { system }\end{array}$ & $\begin{array}{l}\text { Water } \\
\text { management } \\
\text { authorities }\end{array}$ & $\begin{array}{l}\text { Calculates effect of restoration } \\
\text { and mitigation on ecological and } \\
\text { chemical quality of surface } \\
\text { waters. }\end{array}$ & 2013 & $\begin{array}{l}\text { (Junier and } \\
\text { Mostert, 2014) }\end{array}$ \\
\hline $\begin{array}{l}\text { RiBaTox } \\
\text { (under } \\
\text { development) }\end{array}$ & $\begin{array}{l}\text { SOLUTIONS } \\
\text { consortium/ } \\
\text { EU FP7 }\end{array}$ & $\begin{array}{l}\text { Web based } \\
\text { system }\end{array}$ & $\begin{array}{l}\text { Water } \\
\text { authorities }\end{array}$ & $\begin{array}{l}\text { Enables prioritisation, risk } \\
\text { assessment and abatement of } \\
\text { emerging pollutants and their } \\
\text { mixtures. }\end{array}$ & 2015 & $\begin{array}{l}\text { (Brack et al., } \\
2015 \text { ) }\end{array}$ \\
\hline
\end{tabular}




\begin{tabular}{|l|l|l|l|l|l|l|}
\hline Name & $\begin{array}{l}\text { Organisation/ } \\
\text { Project }\end{array}$ & Type & Applicable for & Description & Year & References \\
\hline tDSS & $\begin{array}{l}\text { TAPES } \\
\text { consortium/ } \\
\text { EU Interreg IV } \\
\text { B }\end{array}$ & $\begin{array}{l}\text { Web based } \\
\text { system }\end{array}$ & $\begin{array}{l}\text { Decision makers } \\
\text { within the urban } \\
\text { water cycle }\end{array}$ & $\begin{array}{l}\text { Enables management of CECs } \\
\text { in the urban water cycle. }\end{array}$ & 2015 & This paper \\
\hline
\end{tabular}

\section{3 tDSS design criteria}

The objective of the tDSS, as outlined above, is the management of CECs in the whole urban water cycle, including an integrated assessment of possible mitigation methods beyond technical solutions. In general the management of CECs can be considered a 'wicked' problem, as legislation lacks to assess CECs in specific water bodies. A 'one-size-fits-all' solution does not exist, as this depends on the specific compounds and catchments. Finally, stakeholders differ in their problem perception, urgency and possibilities to take additional measures. Due to this 'wicked' nature, CEC DSSs should be designed to provide the various stakeholders with a common ground, from where discussions on the approach towards CECs can start, as was also experienced in the development of the SOCOPSE DSS. This requires close collaboration with stakeholders and end users, to make sure that the DSS considers all the perspectives of the stakeholders, and to ensure that all relevant variables are included in the DSS (Mitroff and Linstone, 1993; Shim et al., 2002; Wassen et al., 2011).

Furthermore, a strategy to avoid the DSS pitfalls should be part of the design criteria. Therefore flexibility of the DSS should be in focus, together with the stakeholders' possibilities to contribute to the development. It is also important to communicate the results of this approach, to cater for the learning process of the stakeholders and end users during the development, and to heighten the acceptability of the final DSS (Salewicz and Nakayama, 2004; Wassen et al., 2011). Finally, it is crucial to design a DSS that can be further developed (Newman et al., 1999), as the subject of CECs is continuously developing (Diamond et al., 2015) and a CEC DSS will quickly become outdated or obsolete. Table 2 summarises the design criteria for the tDSS.

Table 2. Design criteria for tDSS.

\begin{tabular}{|l|l|}
\hline Criteria & $\begin{array}{l}\text { Solve 'wicked' problem: provide stakeholders with common ground for starting } \\
\text { discussions of CECs, ensure close communication with stakeholders to include all } \\
\text { relevant aspects. }\end{array}$ \\
\hline 2 & $\begin{array}{l}\text { Avoid pitfall 1: account for learning process of stakeholders throughout the DSS } \\
\text { development. }\end{array}$ \\
\hline 3 & $\begin{array}{l}\text { Avoid pitfall 2: heighten acceptability of DSS by giving stakeholders continuous } \\
\text { possibility of contributing throughout the DSS development. }\end{array}$ \\
\hline 4 & Avoid pitfall 3: keep developing and updating DSS to avoid it becoming obsolete. \\
\hline
\end{tabular}

\section{Methodology}

\subsection{Iterative process for the DSS design}

\subsubsection{Problem identification}

Given the tDSS design criteria, the following methodology was used. To make the idea of the tDSS more tangible, a preliminary framework for such a DSS was developed in close collaboration with a key stakeholder (a water research institute), shown in Figure 1. The preliminary framework consisted of three levels: 
(1)

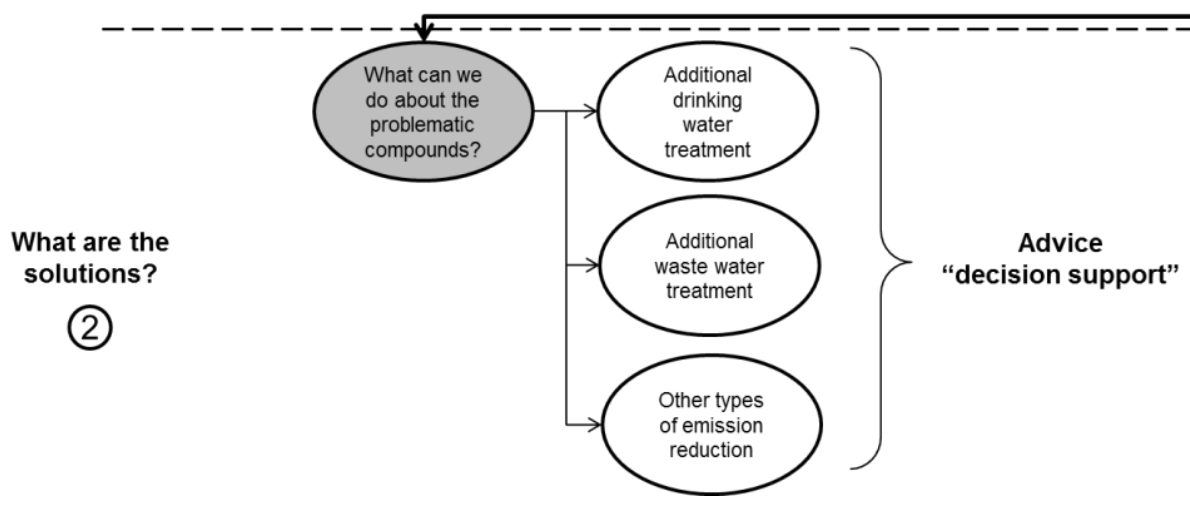

Figure 1. Schematic diagram of preliminary tDSS.

Level 1 - Present is mapping the present situation. This is done based on concentration levels of emerging substances in the surface waters of the catchment investigated. If needed, a post-treatment profile will be made, based on the water treatment technologies currently in place. Using this information a toxicological assessment will be made (Mons et al., 2013; Schriks et al., 2010).

Level 2 - Solutions is assessing which possible measures are available and applicable to the stakeholder, based on the outcomes of Level 1. This is evaluated within the categories additional drinking water treatment, additional wastewater treatment and possibly other types of mitigation methods such as legislation, decentralised removal techniques, awareness raising etc.

Level 3 - Future will simulate various future developments based on consumption, hydrological and/or legislative scenarios and statistics (van der Aa et al., 2011). In this way, the current situation mapped in Level 1 can be adjusted to future scenarios for decisions related to long term effects.

It is important to stress that this is the sketch of the ideal tDSS and an actual tDSS might not be able to fulfil all the desired functions due to cost, time or modelling issues.

With this preliminary framework as a basis, six potential users representing different actors within the water sector, were interviewed to understand the challenges they face when dealing with CECs (in this case a drinking water utility, a wastewater utility, a water board, two water research institutes, and a water management organisation). The interviewed parties were selected to cover the most relevant part of the urban water cycle. This was done to ensure that relevant stakeholder perspectives were heard and incorporated in the DSS. The stakeholders were contacted by e-mail and asked to participate in the interview. Employees relevant for the interviews, were identified by the companies and the interviews were scheduled. During a period of half a year, 21 people were interviewed mostly in groups of two, a few times one to one, and once a group of eight. All interviews were carried out as semi-structured interviews, and done face to face based on six open questions related to the preliminary tDSS framework (see supplementary materials 1). The open questions were deliberately very broad in scope in order to give the interviewed parties the possibility of addressing all the perspectives they felt were important to have included in the DSS. They were used as a starting point 
for a discussion around that specific topic rather than a rigid structure that had to be confined to. The questions and the preliminary framework were emailed to the participants ahead of the interview to encourage the participants to prepare for the interview and ensure that all relevant aspects were touched upon. The interviews were recorded with a digital recorder, and notes were taken. When all interviews were carried out, the recorded interviews were analysed. In this case the interviews were used to obtain an overall idea of the stakeholders struggles with CECs. To analyse the interviews for this purpose, as efficient as possible, the interviews were not transcribed. The audio files were analysed by sampling and clustering (coding) the points raised in the interviews The clusters were each related to a theme, and these main themes were then confirmed with a selected group of stakeholders, see section 3.1.2.

Based on the themes from the interviews, an initial framework for the tDSS was outlined detailing the information that should be available, see section 3.1.3. The tDSS was developed in iterative rounds in which three settings were used:

1. A larger group of stakeholders, water treatment experts and end users, focussing on the initial framework and first prototype

2. A smaller expert group (with people from the involved research institutes), focussing on the second prototype

3. Two DSS experts, focussing on the third prototype

This iterative development ensured continuous confirmation of the requirements for the DSS with the stakeholders, experts and end users. In this way the learning process of the stakeholders, experts and end users on what they need to make a good decision, could be followed and the content of the tDSS adjusted to the outcome of the learning (Salewicz and Nakayama, 2004). The close communication with all involved parties was also intended to improve the acceptability of the tDSS and avoid the second pitfall of many DSSs. The stakeholders could see an actual system develop and influence the process.

Finally, the iterative and ongoing development should prevent the DSS from becoming obsolete. The tDSS must continuously be developed further, in order to meet the expectations of the involved parties.

\subsubsection{Problem formulation}

The problem formulation for the tDSS was done based on the information obtained via the interviews. The overall conclusion from the interviews was that the stakeholders had sufficient information on CECs, but that the relevance of the information often was unknown. Main themes as identified from the analysis of the interviews are highlighted in table 3, for details on how the themes were derived see supplementary materials 2 .

Table 3. Main themes of tDSS derived from interviews

\begin{tabular}{|l|l|}
\hline Topic & Theme \\
\hline CECs & Pathways \\
\cline { 2 - 2 } & Influence on environment \\
\cline { 2 - 2 } & Toxicity \\
\cline { 2 - 2 } & Monitoring/research \\
\cline { 2 - 2 } & Mitigation measures \\
\cline { 2 - 2 } & Cost of mitigation methods \\
\cline { 2 - 2 } & Policy \\
\hline DSS & Integrated approach \\
\cline { 2 - 2 } & Issues \\
\cline { 2 - 2 } & Needs \\
\hline
\end{tabular}


Based on the themes and the points raised in the interviews, questions that the tDSS should answer to fulfil the wishes of the stakeholders were formulated:

1. What are the sources of CECs to water?

a. What is known on adverse effects on human health, the ecosystem or susceptible functions of the water system?

2. What are possible mitigation measures?

i. Which measures are available

ii. How to choose the location of these measures

iii. What are the future robustness of these measures, long term vs. short term

3. Possible future scenarios. The effects of climate change, changes in EU legislation, introduction of new chemicals on the market were mentioned amongst others in the interviews.

4. What are further research needs?

Other important points emerging from the interviews were the wish for a factsheet in the DSS, for easy access to information. Also transparency on the origin of all information included in the system, and the need for more than one answer to an issue was seen as important. An indication whether action on a short term basis should be taken (as response to a (eco)toxicological threat, or a breach of legislation), was an equally important point. Finally the system should be easy-to-use for both experts and non-experts.

The findings of the interviews and the formulated DSS questions were presented to a select group of stakeholders. The relevance of the questions was confirmed and it was decided to focus on the first two themes for the tDSS. This information was seen as most crucial, to enable better management of CECs in the urban water cycle.

\subsubsection{Initial framework}

Based on the problem formulation from the interviews, an initial framework for the content of the tDSS was constructed. This framework detailed the information that should be available in the tDSS in order to address the main questions deducted from the interviews. Figure 2 shows this framework.

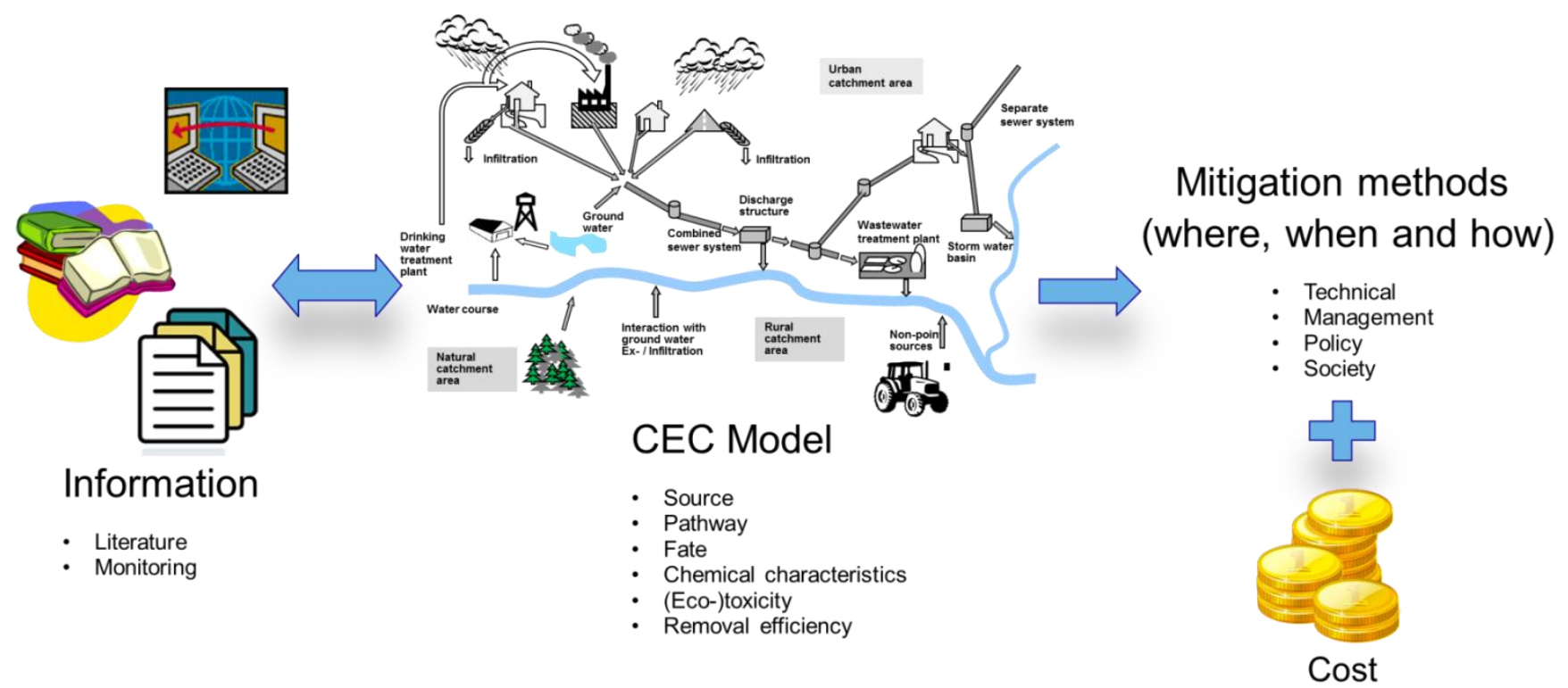

Figure 2. Initial framework of tDSS (water cycle diagram used by curtesey of Dr. E. Christoffels, Erftverband). 
It was agreed with the stakeholders (setting 1) that the tDSS should provide the user with general substance information, such as physical/chemical characteristics and legislative framework, hazard (toxicity), water cycle entrance pathways and associated possible mitigation methods, and the ability to include monitoring results in order to assess environmental and human health risks. Data on water treatment efficiencies should be compiled for various drinking water and wastewater treatment technologies, as well as including decentral technical and non-technical mitigation methods, and where possible, the costs of these methods. The information in the tDSS should be relevant for many types of CECs. This because a variety of CECs from different uses, with different environmental entrances, different environmental fate and different toxicological properties all can be important to various stakeholders.

The stakeholders also agreed, that from the DSS typologies discerned (Power et al. 2002), a data and knowledge driven DSS would fit the requests best.

\subsection{4 tDSS prototypes}

Based on the previously described framework a first tDSS prototype was developed. This prototype was not well received by the involved parties (setting 1), even though the content was as previously agreed upon. There were discussions on the usefulness of the system and the presentation of the content. It was clear that the stakeholders and end-users were not sufficiently involved in the actual development of the prototype.

Based on this experience, an expert group consisting of a smaller group of the parties interviewed was created (setting 2). This group developed a more extensive and detailed framework for the tDSS (Figure 3), where it was ensured that the requests from the stakeholders were met. More elaborate illustrations of the way the content will be presented were also included. This framework was distributed in a wider group and agreed upon by all the involved parties.

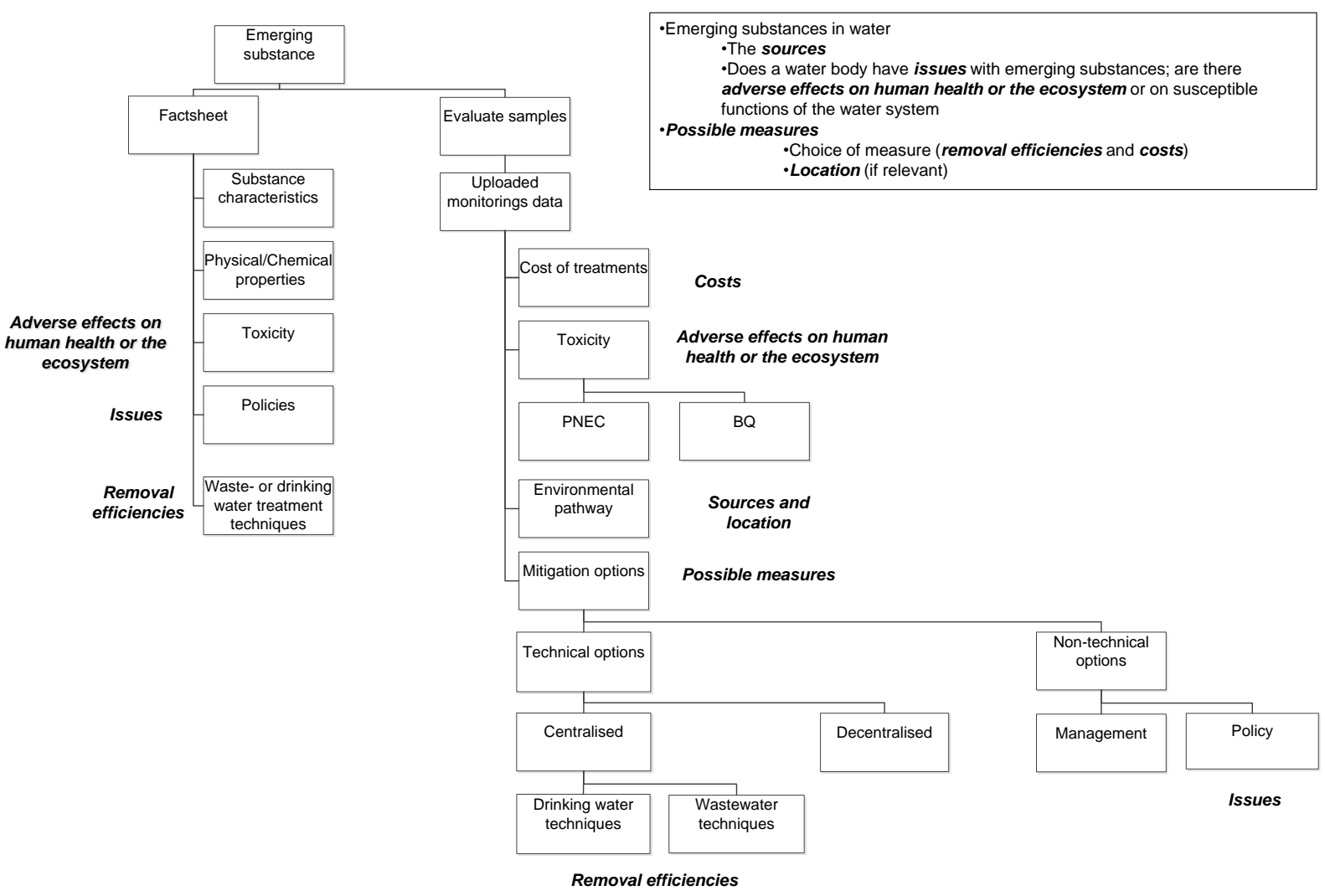

Figure 3. Diagram of information included in the DSS as per stakeholders requests. 
Also a group of water treatment experts were approached to decide which physical/chemical characteristics should be included in the system and which information on the treatment techniques was relevant (see section 4.1, for details). The second prototype was well received, and development of a third and final version was agreed upon. During this final phase (setting 3), the prototype was tested on technical aspects (by a drinking water research company, experienced in developing decision support systems), such as bugs, understanding of screen texts, ease of use of the DSS etc. At the same time, the content of the system was tested, e.g. on the relevance of the diagrams and the information given.

The main lesson from the development phase of the tDSS was that the presentation of the data was crucial, especially since the tDSS was also meant to be used by non-experts. The output should be unambiguous. It is important that this is thoroughly discussed at length and that agreements are well documented.

\subsection{DSS Data sources}

A literature study was used to gather a database of removal efficiencies for the central mitigation options, wastewater and drinking water treatment technologies. Currently the CEC groups industrial by-products, solvents, flame retardants, pharmaceuticals, pesticides and the group other (for compounds from road traffic or surface water usage) are in the tDSS. The focus was on the reduction of concentrations of these chemicals by various commonly used treatment techniques for drinking water and wastewater, such as flotation/coagulation, powdered activated carbon dosage, granular activated carbon filtration, advanced oxidation and membrane filtration. These techniques were chosen as there is a vast amount of data available on their efficiency in removing CECs, that could be fed into the tDSS. Negative efficiencies were not included in the collected data as they can be a result of; lower recovery and detection of substances in influent matrixes; random differences due to high fluctuations of concentrations in influents and effluents; or transformation processes during treatment leading to increasing concentrations of certain substances. Including such data would increase uncertainty and were therefore not included in the current tDSS. The scale of the test (lab, pilot or full scale), the initial concentration, the contact time, the range and average of removal efficiencies measured, and cost per $\mathrm{m}^{3}$ water treated were included to differentiate between seemingly similar treatments. In total, approximately 1000 entries for more than 80 chemicals were collected. So far nine of these compounds are included in the tDSS, namely AMPA, bentazon, carbamazepine, chloridazon, diclofenac, glyphosate, MCPA, metamitron and sulfamethoxazole. These compounds were seen as relevant to the project partners and represented two of the CEC groups the tDSS was built to accommodate namely pharmaceuticals and pesticides.

New data were created for a set of approximately 73 chemicals, which involved the drinking water treatment techniques including; UV/H2O2, nanofiltration, granular activated carbon (GAC) filtration, affinity adsorption (Bäuerlein et al., 2012), and the wastewater treatment techniques powdered activated carbon (PAC), ozonation, retention soil filters (Christoffels et al., 2014), UV $\left(+\mathrm{H}_{2} \mathrm{O}_{2}\right)$, the 1STEP filter (Hulsmann, 2016) and Dissolved Air Flotation (DAF). These new data on removal efficiencies will also be included in the tDSS, except for; the affinity adsorption, as this is a new technique and not yet commercially available; the 1-STEP filter which is currently not suitable for long term treatment; and DAF which is not effective against CECs. An in-depth overview of the data covered in this treatment database including the search criteria and experimental methods used, and analysis of these results, will be published at a later stage.

In addition to central mitigation techniques, a desk study on possible decentralised technical and nontechnical abatement methods was carried out. As for many of these solutions the efficiency and costs are currently difficult to quantify, qualitative information on these issues are provided in the tDSS when relevant to the nine compounds in the system. 


\section{Results and discussion}

\section{1 tDSS content}

In the following the information included in the tDSS to answer the problem formulation is discussed. It is detailed what information is available under the headings of figure 2, section 3.1.4.

\subsubsection{Substance characteristics and physical/chemical properties}

The CECs are characterized by name, CAS number, chemical structure (SMILES) and use(s). Based on the relevance for environmental fate and water treatment, the following chemical-physical properties are included; vapor pressure, melting point, polarizability, solubility, $\log K_{\mathrm{ow}}$ and $\log \mathrm{D}$, flash point, $\mathrm{pK}_{\mathrm{a}}$, molecular mass, total biodegradation and estimated total wastewater treatment removal (de Ridder et al., 2010; Delgado et al., 2012; Schriks et al., 2010). The total biodegradation and total waste water treatment removal are based on the information given in EPI Suite ${ }^{\text {TM }}$ Version 4.11 (EPA, 2012).

\subsubsection{Environmental pathway}

A common way to group substances is based on their type of use, such as pharmaceuticals, pesticides, industrial compounds, personal care products etc. (Schwarzenbach et al., 2006). The source is the place where the substances are originally used, such as household and healthcare sector, agriculture and greenhouses, trade and industry, road traffic and surface water usage such as shipping or recreation. The input routes (environmental pathways) are often comparable for a type of chemical use, as is the legislative framework for their market authorization. Major input routes are wastewater treatment plants (WWTP) effluents and sludge, sewer overflows, industrial discharges, and diffuse entrances such as soil erosion, surface runoff, interflow through the soil and deposition, or direct emission to the surface water through shipping or recreational use. When the environmental pathway of a specific (group) of CECs is known it is often easier to decide on which mitigation options are most suitable as these options are typically coupled to sources and/or input routes. The types, sources, input routes and mitigation categories used in the tDSS are outlined in Figure 4.

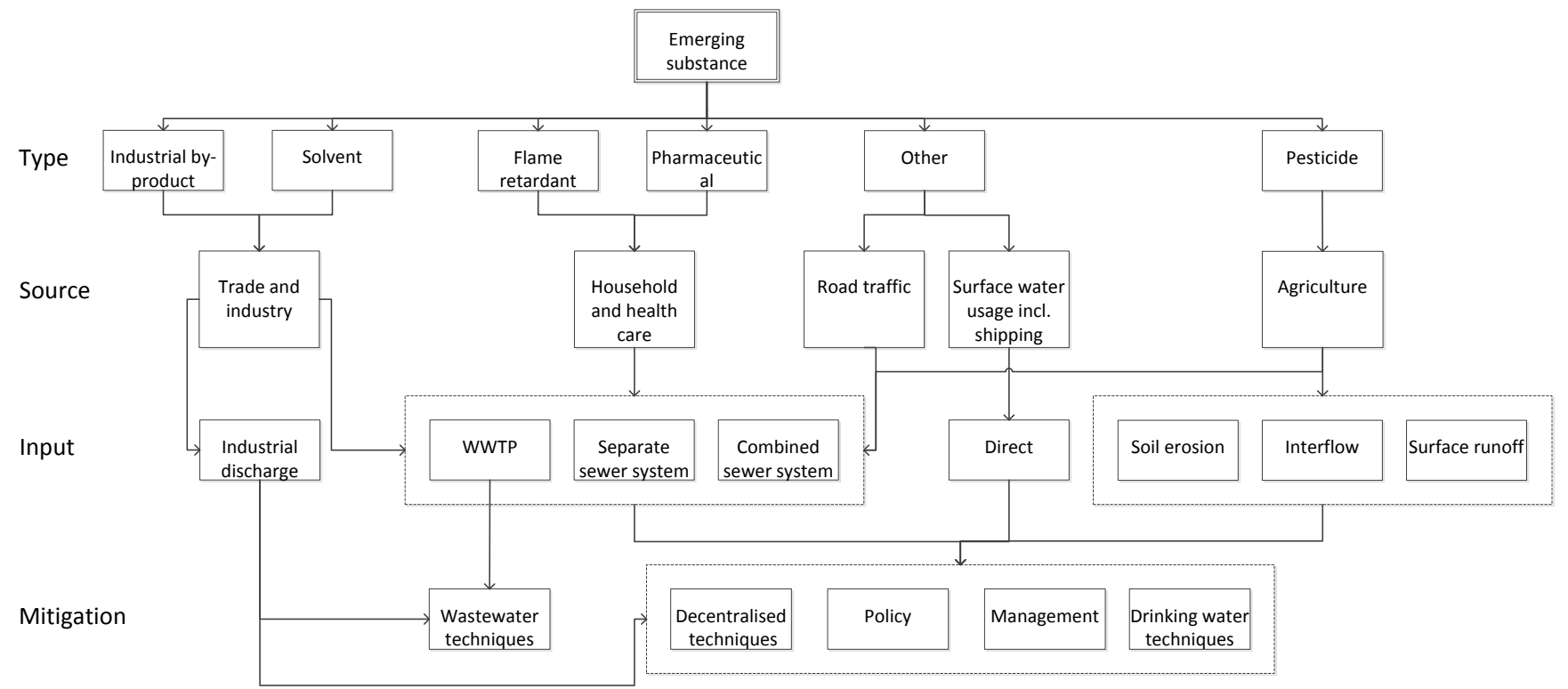

Figure 4. Types, sources, input routes and mitigation categories included in the tDSS.

\subsubsection{Toxicity}

Adverse effects of CECs to both humans and the ecosystem are of importance. To assess the effects and associated risk, information on both toxicity and exposure is necessary and can be used to assess if action is needed and to prioritize the CECs. Human toxicity of CECs and their mixtures, is relevant with regards to drinking water production, agriculture, fishing and recreation. The tDSS is 
firstly focused on drinking water relevance by comparing a (provisional) drinking water limit to occurrence data (Bruce et al., 2010; Schriks et al., 2010). This method can be used for substances when a Tolerable Daily Intake (TDI), Advisable Daily Intake (ADI) or toxicity data, such as No Observed Adverse Effect Levels (NOAELs) from literature, is available. For substances where such information is lacking, as a first conservative approximation, the Threshold of Toxicological Concern (TTC) can be used (Kroes et al., 2000; Kroes et al., 2004; Mons et al., 2013; Schriks et al., 2010).

Predicted No Effect Levels (PNEC) which are relevant for the aquatic ecosystem were added to give an indication of the ecotoxicity of the compound.

\subsubsection{Policies}

Various water quality limits for chemicals in surface waters are included in the $t D S S$ to give water managers insight into whether they are in breach with any legislation. Limits currently included are the Water Framework Directive, the Dutch drinking water law, and the non-legally binding Danube, Meuse and Rhine Memorandum (Drinkwaterwet, 2015; EU, 2000; Wirtz, 2009). The information consists of the name of the compound (for which it is in force), limit value, name of the legislation and country (where it is in force).

\subsubsection{Mitigation options}

Within the $t \mathrm{DSS}$ the mitigation options are categorised based on their technical or non-technical nature as shown in Table 4. The technical measures are split into centralised options such as wastewater and drinking water treatment technologies, and decentralised options, such as technical measures at the source. The non-technical mitigation methods, such as, additional policy making, raising awareness of consumers, or agreements with farmers are divided in to the categories management, policy and society.

Table 4. CEC DSS mitigation categories

\begin{tabular}{|c|c|c|c|c|}
\hline $\begin{array}{l}\text { Main } \\
\text { category }\end{array}$ & Sub category 1 & $\begin{array}{l}\text { Sub } \\
\text { category } 2\end{array}$ & $\begin{array}{l}\text { Examples of mitigation } \\
\text { methods }\end{array}$ & $\begin{array}{l}\text { Currently included } \\
\text { in CEC DSS }\end{array}$ \\
\hline \multirow{3}{*}{ Technical } & \multirow{2}{*}{ Centralised } & $\begin{array}{l}\text { Drinking } \\
\text { water } \\
\text { treatment } \\
\text { techniques }\end{array}$ & $\begin{array}{l}\text { Flotation/coagulation, } \\
\text { activated carbon, advanced } \\
\text { oxidation, membranes and } \\
\text { biological treatment. }\end{array}$ & $\begin{array}{l}\text { All except biological } \\
\text { treatment }\end{array}$ \\
\hline & & $\begin{array}{l}\text { Wastewater } \\
\text { treatment } \\
\text { techniques }\end{array}$ & $\begin{array}{l}\text { Flotation/coagulation, } \\
\text { activated carbon, advanced } \\
\text { oxidation, membranes and } \\
\text { biological treatment. }\end{array}$ & $\begin{array}{l}\text { All except biological } \\
\text { treatment }\end{array}$ \\
\hline & \multicolumn{2}{|l|}{ Decentralised } & $\begin{array}{l}\text { Agriculture - spray free } \\
\text { zones, drip appliances. } \\
\text { Sewer overflow - retention } \\
\text { soil filters. } \\
\text { Household and healthcare - } \\
\text { on site treatment. }\end{array}$ & Yes \\
\hline \multirow[b]{3}{*}{ Non-technical } & \multicolumn{2}{|l|}{ Management } & $\begin{array}{l}\text { Change abstraction source. } \\
\text { Temporarily stop water } \\
\text { intake. }\end{array}$ & Yes \\
\hline & \multicolumn{2}{|l|}{ Policy } & $\begin{array}{l}\text { Restrictions/bans of certain } \\
\text { CECs. }\end{array}$ & $\begin{array}{l}\text { Current restrictions } \\
\text { in place included }\end{array}$ \\
\hline & \multicolumn{2}{|l|}{ Society } & $\begin{array}{l}\text { Increase awareness of the } \\
\text { consequences of using } \\
\text { certain CECs for both } \\
\text { producers and consumers. } \\
\text { Change CEC production } \\
\text { process. }\end{array}$ & $\begin{array}{l}\text { Not included at the } \\
\text { moment due to the } \\
\text { complexity of } \\
\text { quantifying the } \\
\text { effect of such a } \\
\text { measure }\end{array}$ \\
\hline
\end{tabular}


In the $t D S S$, it is possible to choose between the mentioned mitigation subcategories to access information on the various mitigation methods in the selected sub category. The information available is based on the literature studies described in the methodology section. The removal efficiencies of the central water treatment techniques are presented using box plots (Figure 5).

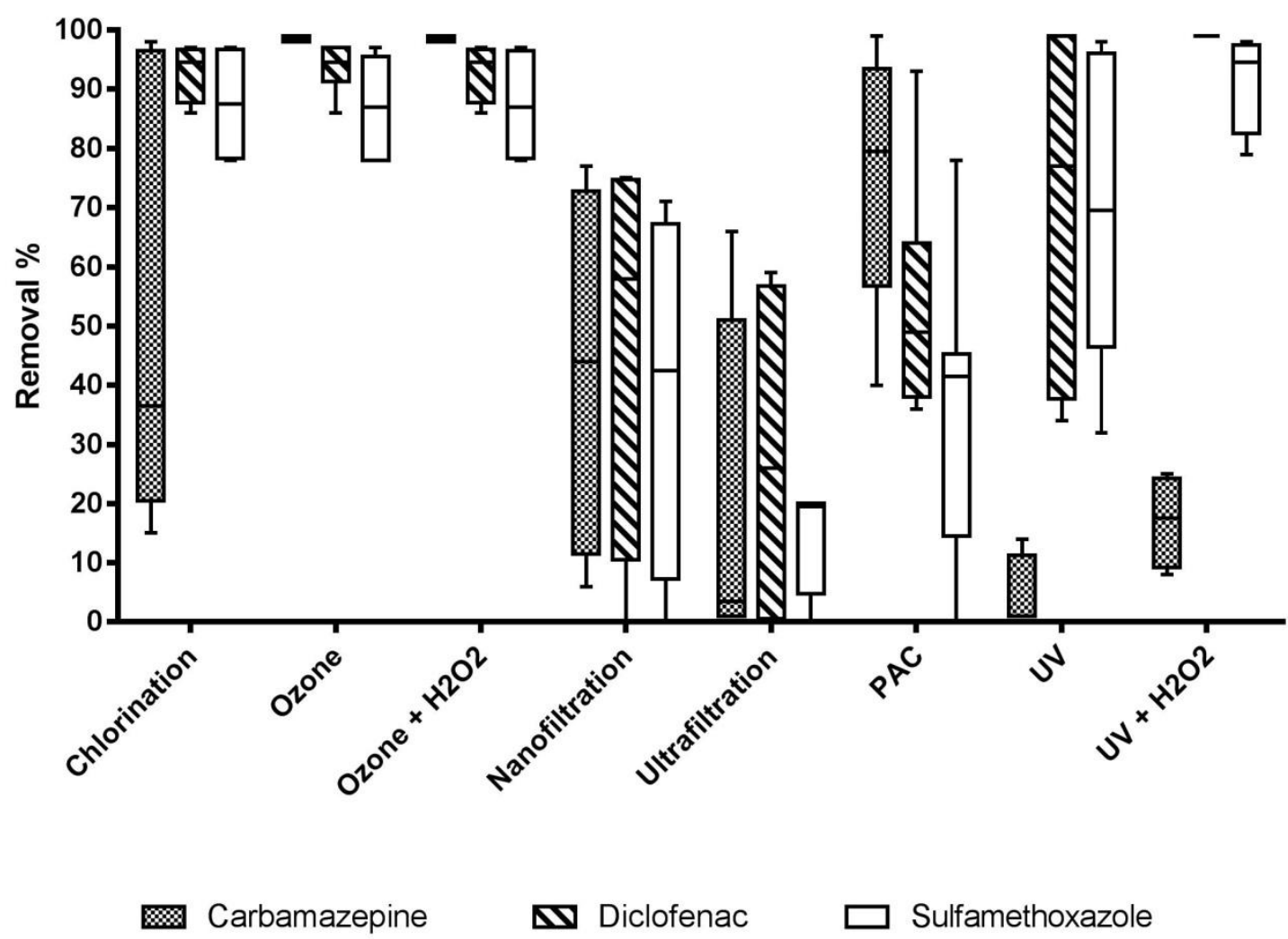

Figure 5. Boxplot of the removal efficiencies of a selection of drinking water treatment techniques for the compounds carbamazepine, diclofenac and sulfamethoxazole from the database. The whiskers of the box plot ( $25^{\text {th }}$ and the $75^{\text {th }}$ percentile) depicts the minimum and maximum of the removal efficiencies.

The information on possible decentralised technical and non-technical abatement methods are given in the form of a list detailing the compound for which; the option is valid, the option itself, possible location of the option, target groups of compounds, removal efficiency if known, costs if known, and references to the literature used.

This information informs the user on which mitigation options are possible for a given compound, their efficiency and where available, the costs of these.

All the above information detailed in sections 4.1 .1 to 4.1 .5 , can only be filled in by individuals with an administrator password. Currently this is limited to the people who developed the system.

\subsubsection{Monitoring measurements}

To assess the situation for a specific water body or location, location-specific monitoring data can be uploaded in the tDSS. In this scenario, the following information is requested: compound(s) measured, location of sample, date, concentration of compounds measured, level of detection/level of quantification (LOD/LOQ) of the analytical technique, analytical-chemical technique used and unit of concentration. Each user can upload this information to the system. This is used to assess the potential drinking water relevance by comparing the monitored concentration to a (provisional) drinking water limit, as also mentioned in section 4.1.3 (Bruce et al., 2010; Schriks et al., 2010). 


\section{2 tDSS output}

summary, the tDSS provides the user with a factsheet containing information of a single substance (Figure 6), and the ability to upload monitoring results and get information relevant for a specific water matrix. The factsheet contains:

- Physico-chemical characteristics, relevant to the removal efficiency for different water treatment techniques.

- Human toxicological values relevant to assess safe exposure levels (ADI,TDI,NOAEL).

- Overview of relevant policies per compound (European Water Framework Directive, local drinking water policies etc.)

- Type, source and input route of the compound.

- Overview of drinking water and wastewater treatment removal efficiencies

- Overview on possible decentral technical and non-technical mitigation methods.
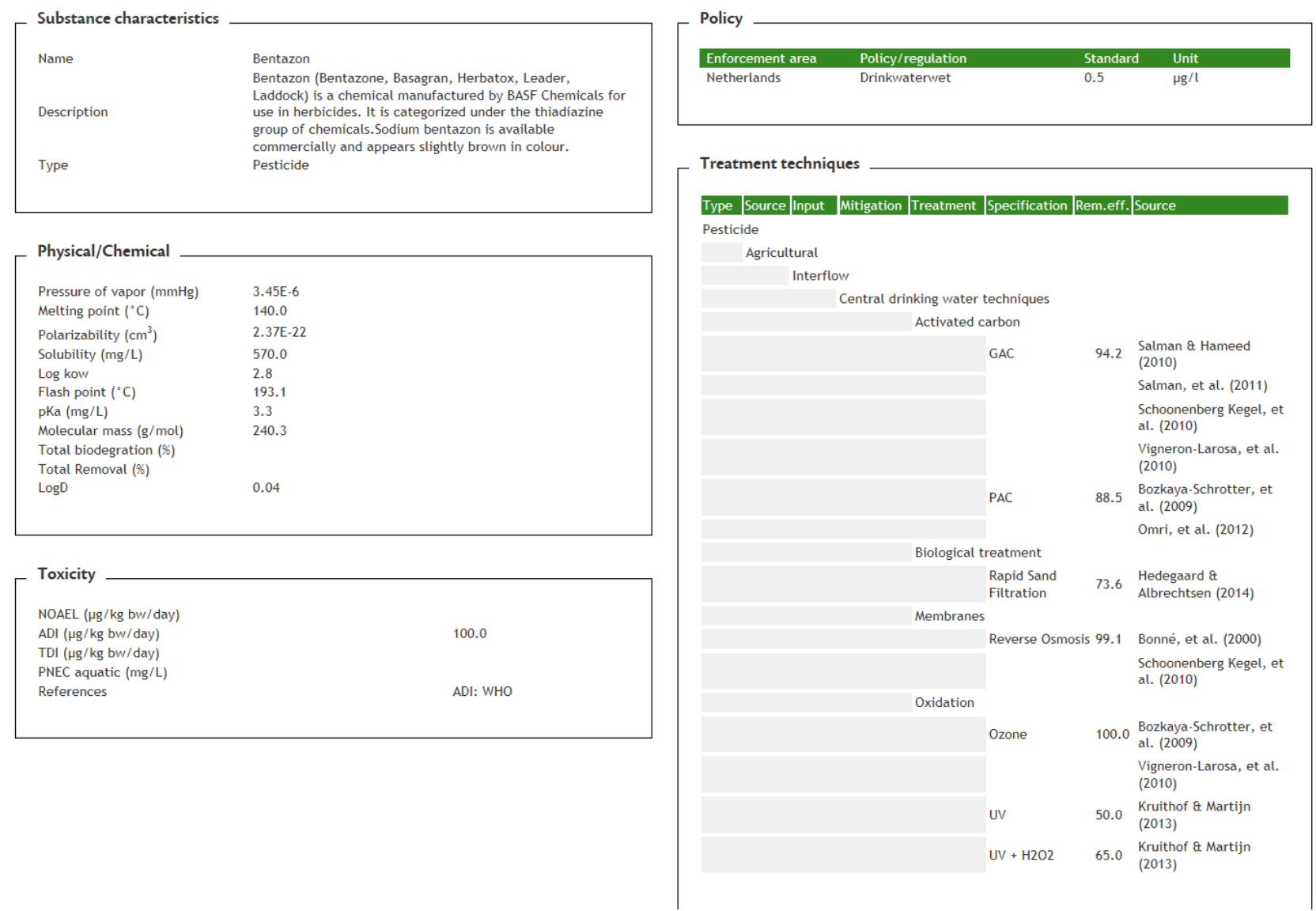

Figure 6. Screenshot of the factsheet for the compound bentazon.

Information on multiple compounds at the same time, can be presented based on the uploaded water quality monitoring results, and provides:

- Assessment of the safety of drinking water production, based on uploaded concentrations and (provisional) drinking water guidelines.

- Eco-toxicological values relevant to assess safe exposure levels (PNEC). At a later stage, a similar approach as for the drinking water safety assessment, can be incorporated to assess adverse effects on ecosystem using relevant eco-toxicological thresholds.

- Diagrams showing the water cycle entry routes for the selected compounds.

- Boxplots of drinking water and wastewater treatment removal efficiencies.

- Overview of relevant policies for the compounds (European Water Framework Directive, local drinking water policies etc.) 
- Overview of decentral technical and non-technical mitigation options.

In Box 1 an example of the decision support the tDSS offers is highligted for the two pharmaceuticals carbamazepine and sulfametoxazole.

\section{Box1: tDSS decision support in case of the two pharmaceuticals carbamazepine and sulfamethoxazole}

\begin{tabular}{|l|l|l|}
\hline General Information & Carbamazepine & Sulfamethoxazole \\
\hline Description & $\begin{array}{l}\text { Carbamazepine (CBZ) is an } \\
\text { analgesic/antiepileptic drug. It was } \\
\text { discovered in Switzerland in 1953. }\end{array}$ & $\begin{array}{l}\text { Sulfamethoxazole (SMZ or SMX), is an antibiotic. It } \\
\text { was used for bacterial and is effective against both } \\
\text { gram negative and positive bacteria such as Listeria } \\
\text { monocytogenes and E. coli. }\end{array}$ \\
\hline Type & Pharmaceutical & Pharmaceutical \\
\hline
\end{tabular}

\begin{tabular}{|l|l|l|l|}
\hline Concentration & Chemical of emerging concern & Carbamazing water benchmark qudyient \\
\hline $0.1 \mu \mathrm{g} / \mathrm{L}$ & Sulfamethoxazole & 0.002 \\
\hline $0.01 \mu \mathrm{g} / \mathrm{L}$ & Pathway compounds
\end{tabular}

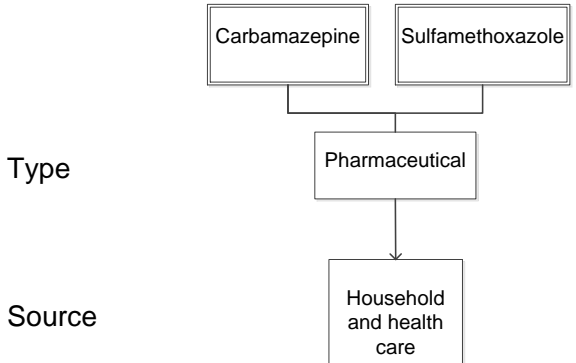

Main entry point of pharmaceuticals to the water cycle.

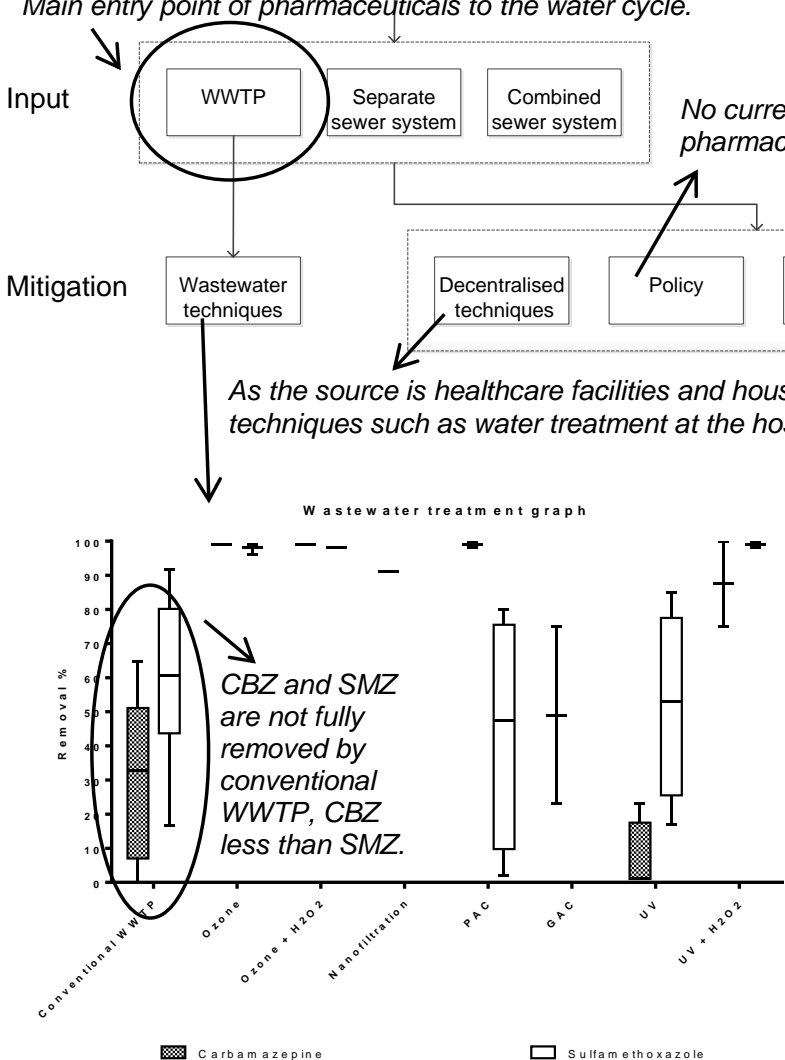

Most additional treatment steps will when optimised remove the pharmaceuticals in wastewater, except UV for CBZ.
Drinking water benchmark quotient is well below 0.1 so no immediate risk to drinking water production (Bruce et al., 2010; Schriks et al., 2010).
PNEC is much higher than measured concentration, so no immediate risk to aquatic environment.
No immediate risk, so decisions such as intake stops not needed.
As main entry point is WWTP removal at drinking water facility will not protect the ecosystem. 


\subsection{Comparison of final tDSS to the original design criteria}

\subsubsection{Adressing the design criteria}

Due to the 'wicked' nature of the problem formulation for the tDSS, the system is designed to provide the various stakeholders with a common ground, where discussions on the approach towards CECs can start. This is done by developing the tDSS in iterative rounds, in close collaboration with stakeholders and end users, to make sure that the tDSS considers all the perspectives of the stakeholders, and to ensure that all relevant variables are included in the tDSS. The tDSS is developed as a data and knowledge driven system. To fulfil the specific wishes of the stakeholders, a factsheet is available, together with clarity on the origin of all information included in the system. The tDSS does not dictate whether action should be taken, as mentioned in section 2.1, the role of DSSs are to support people in making decisions, not to make the decision itself. The tDSS supports the decision making by giving access to relevant CEC information, indicating whether current legislation is breached, if adverse effects may occur, and by providing the user with possible mitigation options (Halden, 2015). The request for information on the susceptible functions of the specific water systems and details on short term vs. long term solutions, has not (yet) been fulfilled. However, it is planned to incorporate these functions into the tDSS in the future. The system is considered simple and easy to use for both experts and non-experts. Effort has been made to make the system self-explanatory with informative screen texts and a few short instruction videos.

The iterative process has helped to avoid typical aforementioned pitfalls for DSSs. It enabled insight to the learning process of the stakeholders and end users, and made clear what information was needed to support them in managing CECs in the urban water cycle. This approach also heightened the acceptability of the tDSS, as was seen in the positive response to the final prototype. To avoid the developed DSS becoming obsolete, it was decided that several stakeholders would continue to develop the tDSS.

In conclusion the design criteria highlighted in section 2.3 have been fulfilled.

\subsubsection{Stakeholder responses}

The stakeholders involved in the process of developing the tDSS were satisfied with the third and last tDSS prototype, the information it contained and the way this information was presented. A follow up of the $t D S S$ named AbatES is now part of the international Watershare network, which contains expert tools for the water sector (www.watershare.eu). The Watershare network has 18 members from 15 countries. Furthermore a Community of Practice has formed for this tool to share their experiences with it, and possibly develop it further.

To assess the usefulness of the system for a new user group that had not been involved in the development, the final prototype was presented to an international group of potential new users to obtain their initial reactions to the system. Also in this setting, the system was well received and seen as useful and relevant. One of the participants, a water treatment manager, stated that the tDSS contained exactly the information he was interested in and it was therefore seen as a useful application.

\subsubsection{Future developments}

The following future developments are planned:

- Inclusion of all information required via literature research, beyond the nine test compounds,

- Inclusion of an ecotoxicology risk calculation, based on uploaded monitoring data or effect measurements;

- Inclusion of evaluation for the complete mixture of compounds, based on uploaded monitoring data;

- Inclusion of other water uses with relevance for human health, next to drinking water;

- Inclusion of more data on (non)-technical abatement options; and 
- Expansion of the possibilities to upload monitoring data, and possibility of sharing monitoring data with others.

\section{Conclusions}

The objective of the tDSS was to facilitate decision makers with the complex task of deciding on effective and efficient strategies to control CECs within their segment of the water cycle. The system had to meet various design criteria such as to provide the various stakeholders with a common ground, where discussions on the approach towards CECs could start, while avoiding common DSS pitfalls. Also, specific stakeholder requests should be fulfilled in the system such as by the inclusion of a factsheet, transparency on the information in the system, an indication of the possible need for short term action, while it being easy-to-use for both experts and non-experts. Via an iterative development process in close communication with the stakeholders, these criteria were met. The final tDSS contains; CEC related information on physical/chemical characteristics, legislative framework, hazards, water cycle entrance pathways and associated possible mitigation methods, it includes the possibility of uploading monitoring data to assess risks in a specific water system. The novelty of the system is the integrated way of addressing mitigation options, such as wastewater and drinking water treatment techniques in combination with decentralised and non-technical methods. The iterative development process and the resulting tDSS was positively received by the involved stakeholders and with interest from potential new users. A follow up of the $t D S S$ named AbatES is now part of the international Watershare network, which contains expert tools for the water sector (www.watershare.eu). Further development is planned to make sure that the system will continue to meet the requirements of current and new users.

\section{Acknowledgements}

The research was carried out in the framework of the European Interreg project TAPES (Transnational Action Programme on Emerging Substances). This project has received European Regional Development Funding through INTERREG IV B. The authors acknowledge all partners in the TAPES project for their input and help, and Erftverband, Fachhochschule Nordwestschweiz, De Watergroep, VITO and Technologiezentrum Wasser for providing additional information for the tDSS. The authors would also like to acknowledge the experts interviewed for their input. Also the authors acknowledge the input given by the Watershare members, especially those forming the Community of Practice on Emerging Substances. 


\section{References}

1. Andersson, H., 2009. Evaluation of the SOCOPSE Decision Support System: A Case Study of Nonylphenol in the River Basin of Viskan. Ekotoxikologiska avdelningen, Uppsala universitet.

2. Angehrn, A.A., Jelassi, T., 1994. Dss Research and Practice in Perspective. Decision Support Systems 12, 267-275.

3. Baartmans, R., Tongeren, W.v., Vlies, J.v.d., Ullrich, S., T. Mattila, Cousins, A.P., Belhaj, M., Munthe, J., Pacyna, J., Sundseth, K., 2009. DSS Handbook SOCOPSE.

4. Bäuerlein, P.S., ter Laak, T.L., Hofman-Caris, R.C.H.M., de Voogt, P., Droge, S.T.J., 2012. Removal of charged micropollutants from water by ion-exchange polymers - Effects of competing electrolytes. Water research 46, 5009-5018.

5. Bergman, Å., Heindel, J.J., Kasten, T., Kidd, K.A., Jobling, S., Neira, M., Zoeller, R.T., Becher, G., Bjerregaard, P., Bornman, R., Brandt, I., Kortenkamp, A., Muir, D., Drisse, M.N.B., Ochieng, R., Skakkebaek, N.E., Byléhn, A.S., Iguchi, T., Toppari, J., Woodruff, T.J., 2013. The impact of endocrine disruption: A consensus statement on the state of the science. Environmental Health Perspectives 121, A104-A106.

6. Beynon, M., Rasmequan, S., Russ, S., 2002. A new paradigm for computer-based decision support. Decision Support Systems 33, 127-142.

7. Brack, W., Altenburger, R., Schüürmann, G., Krauss, M., López Herráez, D., van Gils, J., Slobodnik, J., Munthe, J., Gawlik, B.M., van Wezel, A., Schriks, M., Hollender, J., Tollefsen, K.E., Mekenyan, O., Dimitrov, S., Bunke, D., Cousins, I., Posthuma, L., van den Brink, P.J., López de Alda, M., Barceló, D., Faust, M., Kortenkamp, A., Scrimshaw, M., Ignatova, S., Engelen, G., Massmann, G., Lemkine, G., Teodorovic, I., Walz, K.-H., Dulio, V., Jonker, M.T.O., Jäger, F., Chipman, K., Falciani, F., Liska, I., Rooke, D., Zhang, X., Hollert, H., Vrana, B., Hilscherova, K., Kramer, K., Neumann, S., Hammerbacher, R., Backhaus, T., Mack, J., Segner, H., Escher, B., de Aragão Umbuzeiro, G., 2015. The SOLUTIONS project:

Challenges and responses for present and future emerging pollutants in land and water resources management. Science of The Total Environment 503-504, 22-31.

8. Bruce, G.M., Pleus, R.C., Snyder, S.A., 2010. Toxicological relevance of pharmaceuticals in drinking water. Environmental Science and Technology 44, 5619-5626.

9. CEFIC, 2013. Facts \& figures 2013. The European chemical industry., Brussels (available via www.cefic.org).

10. Christensen, F.M., Eisenreich, S.J., Rasmussen, K., Sintes, J.R., Sokull-Kluettgen, B., Van De Plassche, E.J., 2011. European experience in chemicals management: Integrating science into policy. Environmental Science and Technology 45, 80-89.

11. Christoffels, E., Mertens, F.M., Kistemann, T., Schreiber, C., 2014. Retention of pharmaceutical residues and microorganisms at the Altendorf retention soil filter. Water Science and Technology 70, 1503-1509.

12. Coppens, L.J.C., van Gils, J.A.G., ter Laak, T.L., Raterman, B.W., van Wezel, A.P., 2015. Towards spatially smart abatement of human pharmaceuticals in surface waters: Defining impact of sewage treatment plants on susceptible functions. Water research 81, 356-365.

13. Courtney, J.F., 2001. Decision making and knowledge management in inquiring organizations: Toward a new decision-making paradigm for DSS. Decision Support Systems 31, 17-38.

14. de Jongh, C.M., Kooij, P.J.F., de Voogt, P., ter Laak, T.L., 2012. Screening and human health risk assessment of pharmaceuticals and their transformation products in Dutch surface waters and drinking water. Science of the Total Environment 427-428, 70-77.

15. Debroux, J.F., Soller, J.A., Plumlee, M.H., Kennedy, L.J., 2012. Human Health Risk Assessment of Non-Regulated Xenobiotics in Recycled Water: A Review. Human and Ecological Risk Assessment 18, 517-546.

16. Delpla, I., Monteith, D.T., Freeman, C., Haftka, J., Hermens, J., Jones, T.G., Baurès, E., Jung, A.V., Thomas, O., 2014. A decision support system for drinking water production integrating health risks assessment. International Journal of Environmental Research and Public Health 11, 7354-7375.

17. Diamond, M.L., de Wit, C.A., Molander, S., Scheringer, M., Backhaus, T., Lohmann, R., Arvidsson, R., Bergman, T., Hauschild, M., Holoubek, I., Persson, L., Suzuki, N., Vighi, M., Zetzsch, C., 2015. Exploring the planetary boundary for chemical pollution. Environment international 78, 8-15.

18. Dietrich, D.R., Aulock, S., Marquardt, H., Blaauboer, B., Dekant, W., Kehrer, J., Hengstler, J., Collier, A., Gori, G.B., Pelkonen, O., Lang, F., Barile, F.A., Nijkamp, F.P., Stemmer, K., Li, A., Savolainen, K., Hayes, A.W., Gooderham, N., Harvey, A., 2013. Scientifically unfounded 
precaution drives European Commission's recommendations on EDC regulation, while defying common sense, well-established science and risk assessment principles. Chemico-biological interactions 205, A1-5.

19. EPA, U., 2007. Hazard Analysis Critical Control Point (HACCP) Strategies for Distribution System Monitoring, Hazard Assessment and Control.

20. EU, 2000. Directive of the European Parliament and of the Council 2000/60/EC Establishing a Framework for Community Action in the Field of Water Policy. Official Journal of the European Union C513.

21. EU, 2006. Regulation (EC) No 1907/2006 of the European Parliament and of the Council of 18 December 2006 concerning the Registration, Evaluation, Authorisation and Restriction of Chemicals (REACH), Establishing a European Chemicals Agency, Amending Directive 1999/45/EC and Repealing Council Regulation (EEC) No 793/93 and Commission Regulation (EC) No 1488/94 as well as Council Directive 76/769/EEC and Commission Directives 91/155/EEC, 93/67/EEC, 93/105/EC and 2000/21/EC Official Journal of the European Union L 396/1.

22. Giupponi, C., 2007. Decision Support Systems for implementing the European Water Framework Directive: The MULINO approach. Environmental Modelling and Software 22, 248258.

23. Halden, R.U., 2015. Epistemology of contaminants of emerging concern and literature metaanalysis. Journal of hazardous materials $282,2-9$.

24. Hocking, V.T., Brown, V.A., Harris, J.A., 2015. Tackling wicked problems through collective design. Intelligent Buildings International.

25. Holsapple, C.W., 2003. Decision Support Systems, Encyclopedia of Information Systems.

26. Houtman, C.J., 2010. Emerging contaminants in surface waters and their relevance for the production of drinking water in Europe. Journal of Integrative Environmental Sciences 7, 271295.

27. Houtman, C.J., Kroesbergen, J., Lekkerkerker-Teunissen, K., van der Hoek, J.P., 2014. Human health risk assessment of the mixture of pharmaceuticals in Dutch drinking water and its sources based on frequent monitoring data. The Science of the total environment 496, 5462.

28. Hulsmann, A., 2016. TAPES TRANSNATIONAL ACTION PROGRAM ON EMERGING SUBSTANCES - FINAL PROJECT REPORT, http://www.tapes-interreg.eu/, p. 209.

29. Junier, S., Mostert, E., 2014. A decision support system for the implementation of the Water Framework Directive in the Netherlands: Process, validity and useful information. Environmental Science and Policy 40, 49-56.

30. Kroes, R., Galli, C., Munro, I., Schilter, B., Tran, L., Walker, R., Wurtzen, G., 2000. Threshold of toxicological concern for chemical substances present in the diet: a practical tool for assessing the need for toxicity testing. Food and chemical toxicology : an international journal published for the British Industrial Biological Research Association 38, 255-312.

31. Kroes, R., Renwick, A.G., Cheeseman, M., Kleiner, J., Mangelsdorf, I., Piersma, A., Schilter, B., Schlatter, J., van Schothorst, F., Vos, J.G., Würtzen, G., 2004. Structure-based thresholds of toxicological concern (TTC): guidance for application to substances present at low levels in the diet. Food and Chemical Toxicology 42, 65-83.

32. McBride, N., 1997. The rise and fall of an executive information system: A case study. Information Systems Journal 7, 277-287.

33. McCown, R.L., 2002. Changing systems for supporting farmers' decisions: Problems, paradigms, and prospects. Agricultural Systems 74, 179-220.

34. Mitroff, I.I., Linstone, H.A., 1993. The unbounded mind: breaking the chains of traditional business thinking. Oxford University Press.

35. Mons, M.N., Heringa, M.B., van Genderen, J., Puijker, L.M., Brand, W., van Leeuwen, C.J., Stoks, P., van der Hoek, J.P., van der Kooij, D., 2013. Use of the Threshold of Toxicological Concern (TTC) approach for deriving target values for drinking water contaminants. Water research 47, 1666-1678.

36. Mysiak, J., Giupponi, C., Rosato, P., 2005. Towards the development of a decision support system for water resource management. Environmental Modelling and Software 20, 203-214.

37. Newman, S., Lynch, T., Plummer, A.A., 1999. Success and failure of decision support systems: Learning as we go. Proceedings of the American Society of Animal Science.

38. Nohynek, G.J., Borgert, C.J., Dietrich, D., Rozman, K.K., 2013. Endocrine disruption: Fact or urban legend? Toxicology letters 223, 295-305. 
39. Power, D.J., 2002. Decision Support Systems: Concepts and Resources for Managers. Quorum Books.

40. Power, D.J., Sharda, R., 2009. Decision Support Systems, in: Nof, S.Y. (Ed.), Springer Handbook of Automation. Springer Berlin Heidelberg, pp. 1539-1548.

41. Rauscher, H.M., 1999. Ecosystem management decision support for federal forests in the United States: A review. Forest Ecology and Management 114, 173-197.

42. Richardson, S.D., 2012. Environmental mass spectrometry: emerging contaminants and current issues. Analytical chemistry 84, 747-778.

43. Richardson, S.D., Ternes, T.A., 2011. Water analysis: emerging contaminants and current issues. Analytical chemistry 83, 4614-4648.

44. Rittel, H.W.J., Webber, M.M., 1973. Dilemmas in a general theory of planning. Policy Sciences 4, 155-169.

45. Salewicz, K.A., Nakayama, M., 2004. Development of a web-based decision support system (DSS) for managing large international rivers. Global Environmental Change 14, 25-37.

46. Sauvé, S., Desrosiers, M., 2014. A review of what is an emerging contaminant. Chemistry Central Journal 8, 15.

47. Schirmer, K., Schirmer, M., 2008. Who is chasing whom? A call for a more integrated approach to reduce the load of micro-pollutants in the environment, Water Science and Technology, pp. 145-150.

48. Schriks, M., Heringa, M.B., van der Kooi, M.M., de Voogt, P., van Wezel, A.P., 2010. Toxicological relevance of emerging contaminants for drinking water quality. Water research 44, 461-476.

49. Schwarzenbach, R.P., Escher, B.I., Fenner, K., Hofstetter, T.B., Johnson, C.A., Von Gunten, U., Wehrli, B., 2006. The challenge of micropollutants in aquatic systems. Science 313, 10721077.

50. Shim, J.P., Warkentin, M., Courtney, J.F., Power, D.J., Sharda, R., Carlsson, C., 2002. Past, present, and future of decision support technology. Decision Support Systems 33, 111-126.

51. van der Aa, N.G., Kommer, G.J., van Montfoort, J.E., Versteegh, J.F., 2011. Demographic projections of future pharmaceutical consumption in the Netherlands. Water science and technology : a journal of the International Association on Water Pollution Research 63, 825831.

52. Vandenberg, L.N., Colborn, T., Hayes, T.B., Heindel, J.J., Jacobs, D.R., Lee, D.H., Shioda, T., Soto, A.M., vom Saal, F.S., Welshons, W.V., Zoeller, R.T., Myers, J.P., 2012. Hormones and endocrine-disrupting chemicals: Low-dose effects and nonmonotonic dose responses. Endocrine Reviews 33, 378-455.

53. Wassen, M.J., Runhaar, H., Barendregt, A., Okruszko, T., 2011. Evaluating the role of participation in modeling studies for environmental planning. Environment and Planning B: Planning and Design 38, 338-358.

54. WHO/IWA, 2009. Water safety plan manual (WSP manual) Step-by-step risk management for drinking-water suppliers, in: Organization, W.H., Association, I.W. (Eds.), p. 108.

55. Xu, Y.P., Booij, M.J., Mynett, A.E., 2007. An appropriateness framework for the Dutch Meuse decision support system. Environmental Modelling and Software 22, 1667-1678. 


\section{Decision support for water quality management of contaminants of emerging concern}

Supplementary Material 1: Discussion points

1. What kind of decisions do you need to make with regards to the management of emerging substances within your organisation?

2. In general when making decisions regarding the management of emerging substances within your organisation what do you struggle with?

3. Do you feel that lack of knowledge in certain areas are preventing you from making informed decisions on how to manage emerging substances within your organisation? If yes in which areas are knowledge missing?

4. How should an ideal Decision Support System in your opinion help you make the right decisions?

5. What kind of output would you like/expect from a Decision Support System that should help you make informed decisions with regards to the management of emerging substances within your organisation?

6. What possible barriers could you think of that might prevent your organisation from implementing a solution given by the Decision Support System? 


\section{Decision support for water quality management of contaminants of emerging concern}

Supplementary Material 2: Derived themes from interviews

\begin{tabular}{|c|c|c|c|}
\hline & Theme & Points from interview & Stakeholder \\
\hline \multirow[t]{7}{*}{ CECs } & Pathways of CECs & $\begin{array}{l}\text { - Total pathway (above and under } \\
\text { catchment) } \\
\text { - Identify important players with regards to } \\
\text { - } \text { Insight into the source (linked to } \\
\text { measures) } \\
\text { - Mass balance } \\
\text { - Total emissions } \\
\text { - Effluent emissions }\end{array}$ & $\begin{array}{l}\text { drinking water utility, } \\
\text { wastewater utility, } \\
\text { water board, and } \\
\text { water management } \\
\text { organisation }\end{array}$ \\
\hline & $\begin{array}{l}\text { CEC influence on } \\
\text { environment }\end{array}$ & $\begin{array}{ll} & \text { Effect of CECs on ecology } \\
\text { - } & \text { Species related } \\
\text { - } & \text { Target species } \\
\text { - } & \text { Sensitive stretches } \\
& \text { Impact of WWTP at sensitive stretches of } \\
& \text { rivers } \\
\end{array}$ & $\begin{array}{l}\text { wastewater utility, } \\
\text { water board, water } \\
\text { research institute }\end{array}$ \\
\hline & Toxicity of CECs & $\begin{array}{l}\text { - } \text { Toxic effects } \\
\text { - Is there an issue? } \\
\text { - Mixture toxicology } \\
\text { Toxicity of groups of compounds } \\
\text { - Long term } \\
\text { Metabolites and their toxicity } \\
\quad \quad \text { Effect measurements before and } \\
\text { after treatment } \\
\text { - More stable } \\
\text { Cumulative effect of concentrations } \\
\text { already in the water and legal discharge }\end{array}$ & $\begin{array}{l}\text { drinking water utility, } \\
\text { wastewater utility, } \\
\text { water board, water } \\
\text { research institute, } \\
\text { water management } \\
\text { organisation }\end{array}$ \\
\hline & Monitoring/research & $\begin{aligned} \text { - Where should research money go } \\
\text { Set-up of monitoring programme: } \\
\text { - Which compounds } \\
\text { Best way of monitoring (bioassay- } \\
\text { measurements-consumption) } \\
\text { How much do we need to monitor } \\
\text { (screening, relevance, ecology) } \\
\text { Based on legal limits (to comply } \\
\text { with legislation) }\end{aligned}$ & $\begin{array}{l}\text { wastewater utility, } \\
\text { water board, water } \\
\text { research institutes }\end{array}$ \\
\hline & $\begin{array}{l}\text { Mitigation } \\
\text { measures }\end{array}$ & 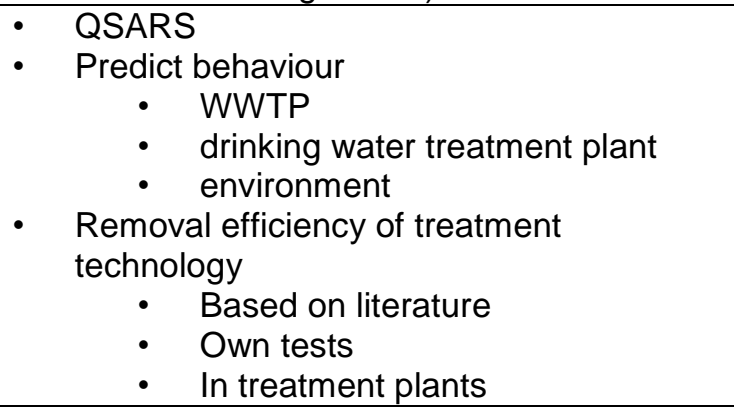 & $\begin{array}{l}\text { drinking water utility, } \\
\text { wastewater utility, } \\
\text { water board, water } \\
\text { research institute, } \\
\text { water management } \\
\text { organisation }\end{array}$ \\
\hline & Cost & $\begin{array}{l}\text { - Where can I use the EUR best? } \\
\text { - Cost of measures } \\
\cdot \quad \text { Cost of adaptation of WWTP } \\
\text { - Cost monitoring }\end{array}$ & $\begin{array}{l}\text { drinking water utility, } \\
\text { wastewater utility, } \\
\text { water board, water } \\
\text { management } \\
\text { organisation }\end{array}$ \\
\hline & Policy & - $\quad$ Factsheets related to legislation (health & drinking water utility, \\
\hline
\end{tabular}




\begin{tabular}{|c|c|c|c|}
\hline & & $\begin{array}{ll} & \text { based values) } \\
\text { - } & \text { Legislation is too slow } \\
\text { - } & \text { EU legislation is too political } \\
& \text { Lack of legislative limits (EU based on } \\
& \text { annual averages, issue for pesticides) } \\
\text { - } & \text { Lack of norms (threshold limits) } \\
& \text { EU aim for simpler water treatment vs. } \\
& \text { need to deal with CECs }\end{array}$ & $\begin{array}{l}\text { wastewater utility, } \\
\text { water board, water } \\
\text { research institutes, } \\
\text { water management } \\
\text { organisation }\end{array}$ \\
\hline \multirow[t]{3}{*}{ DSS } & $\begin{array}{l}\text { DSS integrated } \\
\text { approach }\end{array}$ & 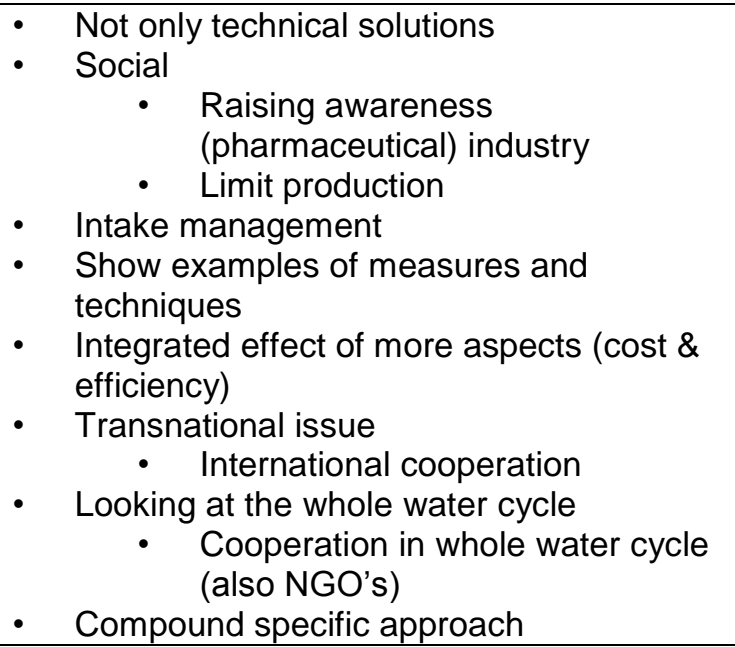 & $\begin{array}{l}\text { drinking water utility, } \\
\text { wastewater utility, } \\
\text { water board, water } \\
\text { research institutes, } \\
\text { water management } \\
\text { organisation }\end{array}$ \\
\hline & DSS issues & $\begin{array}{l}\text { - Lack of monitoring data } \\
\text { - } \quad \text { Sanguage (in DSS) } \\
\text { water not safe) } \\
\text { - Will there be enough information on level } \\
\text { (concentration, load, use) of ES for local } \\
\text { use } \\
\text { - Can the DSS consider all (important) } \\
\text { aspects } \\
\text { - The interest in CECs is variable } \\
\text { No harmonisation in the water cycle } \\
\text { (different players have different } \\
\text { approaches to established issues) } \\
\text { - Validation (who, how) } \\
\text { Validity of possible toxicological } \\
\text { - } \text { Coaluation } \\
\text { - Needexity! } \\
\text { - Who controls the DSS } \\
\text { - Does it already exist } \\
\text { Who will pay (for the mitigation measures) }\end{array}$ & $\begin{array}{l}\text { drinking water utility, } \\
\text { wastewater utility, } \\
\text { water board, water } \\
\text { research institutes, } \\
\text { water management } \\
\text { organisation }\end{array}$ \\
\hline & DSS needs & $\begin{array}{ll} & \text { Factsheet! } \\
\text { - } & \text { Regionally adaptable } \\
\text { - } & \text { Simple } \\
\text { - } & \text { Monvincing } \\
\text { - } & \text { Easy to use } \\
\text { - } & \text { For policy makers } \\
\text { - } & \text { Transpanagement } \\
\text { - } & \text { Tailored to user } \\
\text { - } & \text { Realistic } \\
\text { - } & \text { Sive advice } \\
\text { - } & \text { Trafficic light to indicate if action is needed } \\
\end{array}$ & $\begin{array}{l}\text { drinking water utility, } \\
\text { wastewater utility, } \\
\text { water board, water } \\
\text { research institute, } \\
\text { water management } \\
\text { organisation }\end{array}$ \\
\hline
\end{tabular}

